\title{
DIFFERENCES IN PHYSICOCHEMICAL, MINERAL AND NUTRACEUTICAL PROPERTIES BETWEEN REGULAR, LIGHT AND ZERO BEERS
}

\author{
DOLORES MUY-RANGEL ${ }^{1}$, VANIA URÍAS-ORONA ${ }^{2}$, JOSÉ B. HEREDIA ${ }^{1}$, LUIS \\ HERNÁNDEZ-GARCÍA ${ }^{3}$, WERNER RUBIO-CARRASCO ${ }^{1}$, LAURA CONTRERAS-ANGULO ${ }^{1}$, \\ ROSALBA CONTRERAS-MARTÍNEZ ${ }^{1}$, GUILLERMO NIÑO-MEDINA ${ }^{4 *}$
}

\begin{abstract}
${ }^{1}$ Centro de Investigación en Alimentación y Desarrollo, A.C., Coordinación Culiacán, Laboratorio de Tecnología de Alimentos. Carretera a Culiacán-El Dorado, km. 5.5, C.P. 80129, Culiacán, Sinaloa, México

${ }^{2}$ Universidad Autónoma de Nuevo León, Facultad de Salud Pública y Nutrición, Laboratorio de Química de Alimentos, Av. Dr. Eduardo Aguirre Pequeño y Yuriria, C.P. 64460, Col. Mitras Centro, Monterrey, Nuevo León, México

${ }^{3}$ Catedrático CONACYT-Centro de Investigación e Innovación Tecnológica, Instituto Tecnológico de Nuevo León, Av. De la Alianza No. 507, PIIT, Carretera Monterrey-Aeropuerto Km. 10, C.P. 66628, Apodaca, Nuevo León, México

${ }^{4}$ Universidad Autónoma de Nuevo León, Facultad de Agronomía, Laboratorio de Química y Bioquímica, Francisco Villa S/N, Col. Ex-Hacienda El Canadá, C.P. 66050, General Escobedo, Nuevo León, México
\end{abstract}

*corresponding author: guillermo.ninomd@uanl.edu.mx

Manuscript received: November 2017

\begin{abstract}
The differences in physicochemical, mineral and nutraceutical properties between regular, light and zero beers were evaluated. The $\mathrm{pH}$, titratable acidity and colour values of all beers were in the range quality criteria of beer industry. On the other hand, zero beer showed the highest content of $\mathrm{Ca}, \mathrm{Mg}, \mathrm{K}$ and $\mathrm{Na}$, light beer obtained the highest content in $\mathrm{Cu}, \mathrm{Zn}$ and $\mathrm{Fe}$, while $\mathrm{Mn}$ was detected only in regular beer. The highest content of total phenols was found in regular beer, followed by zero and light beers, while in total flavonoids, zero beer obtained the highest content, followed by regular and light beers. Considering the in ABTS, DPPH, FRAP and ORAC antioxidant capacity the results were: regular beer $>$ zero beer $>$ light beer.
\end{abstract}

\section{Rezumat}

$\mathrm{Au}$ fost evaluate proprietățile fizico-chimice precum și conținutul în minerale și nutraceutice a berilor normale, ușoare și fără alcool. Berile analizate s-au încadrat în normele de calitate din industria berii privind valorile de $\mathrm{pH}$, aciditate şi de culoare. Pe de altă parte, berea fără alcool a prezentat cel mai mare conținut de $\mathrm{Ca}, \mathrm{Mg}, \mathrm{K}$ și $\mathrm{Na}$, berea uşoară a prezentat cel mai mare conținut de $\mathrm{Cu}, \mathrm{Zn}$ și Fe, în timp ce Mn a fost detectat doar în berea normală. Cel mai mare conținut de fenoli totali a fost găsit în berea normală, urmată de berea fără alcool și de cea ușoară. Conținutul total de flavonoide a fost maxim pentru berea fără alcool, urmat de cea normală și ușoară. Din punct de vedere al capacității antioxidante, evaluată prin metodele ABTS, DPPH, FRAP și ORAC, rezultatele au fost următoarele: bere normală > bere fără alcool > bere ușoară.

Keywords: physicochemical parameters, mineral composition, nutraceutical properties, regular light and zero beers

\section{Introduction}

Beer, a complex beverage made from barley (malt), hop, water and yeast is one of the most consumed alcoholic beverages. Is rich in nutrients as well as nonnutrient compounds including carbohydrates, amino acids, minerals, vitamins and phenolics [7]. Beer is available in a wide range of styles and flavours, and when is consumed in sensible amounts it can contribute to a healthy diet [10]. Quality analysis of beer in the brewery laboratory includes numerous determinations such as alcohol content, $\mathrm{pH}$, titratable acidity and colour, among others [19]. Also, phenolic compounds contribute directly to some quality characteristics of beer, such as the colour, flavour, and astringency, and they also protect raw materials from oxidative degradation throughout the brewing process [5].
Substantial numbers of alcohol-related cancers as breast, colorectum, head and neck, oesophagus and liver cancers are associated with consumption of more than $24 \mathrm{~g}$ per day for men (more than two drinks per day) and more than $12 \mathrm{~g}$ per day for women (more than one drink per day) [3]. On the other hand, epidemiological studies suggested that regular and moderate consumption of beer confers cardiovascular protection. Part of this protective effect of beer is due to their alcoholic content (ethanol) and another part to their non-alcoholic components as phenolics [6, 10]. In addition, due to health, diet and safety reasons an increasing demand for low-alcohol and alcoholfree beers has been observed in the last years [23]. Because of the diverse options of different alcohol content in beers for consumers in the market, it is necessary to evaluate their differences in physico- 
FARMACIA, 2018, Vol. 66, 4

chemical, nutritional and nutraceutical attributes. For this reason, the aim of this work was to evaluate and compare the physicochemical (alcohol content, $\mathrm{pH}$, titratable acidity, colour) mineral ( $\mathrm{K}, \mathrm{Na}, \mathrm{Ca}, \mathrm{Mg}$, $\mathrm{Fe}, \mathrm{Zn}, \mathrm{Cu}, \mathrm{Mn}$ ) and nutraceutical (total phenols, total flavonoids, ABTS, DPPH, FRAP, ORAC) properties between regular, light and zero beers.

\section{Materials and Methods}

\section{Beer samples}

Three samples of $355 \mathrm{~mL}$ of every type of beer (regular, light and zero) from different lot number were purchased from a local supermarket in the second week of January 2017 and stored at $5^{\circ} \mathrm{C}$. The three types of beer were from the same brand, the alcohol content reported in label was $4.5 \%$ for regular beer, $3.9 \%$ for light beer and $0.0 \%$ for zero beer and all samples were produced during 2016. According to labels, regular and light beers were produced using the basic raw materials malt, hop, water and yeast, while zero beer indicated the use of water, barley malt, corn, hop, natural beer flavour, natural malt flavour and potassium citrate.

\section{Physicochemical parameters}

Samples were degassed by stirring $30 \mathrm{~mL}$ at $100 \mathrm{rpm}$ for $20 \mathrm{~min}$ at room temperature and then were filtered using Whatman 1 filter paper. The $\mathrm{pH}$ was read and after that, samples were titrated with $0.1 \mathrm{~N} \mathrm{NaOH}$ to a pH 8.2 using an Mettler-Toledo automatic titration equipment T50 titrator (Greifensee, Switzerland) according to Association of Official Analytical Chemist methods [2]. Colour was determined according to Popescu et al [19] by reading absorbance of the sample at $430 \mathrm{~nm}\left(\mathrm{Abs}_{430}\right)$ in a Jenway $6705 \mathrm{UV} /$ Vis spectrophotometer (Stone, Staffordshire, UK) using $1 \mathrm{~cm}$ cuvettes and the colour of the samples were calculated in EBC (European Brewery Convention) units (colour $=\mathrm{Abs}_{430}$ *24) and ASBC (American Society of Brewing Chemists) units (colour $=\mathrm{Abs}_{430}$ * 12.7).

\section{Mineral composition}

Mineral analysis was performed based on Association of Official Analytical Chemist methods [2] using an Agilent atomic absorption 240FS spectrometer (Santa Clara, CA, United States). Briefly, $5 \mathrm{~mL}$ of $3 \mathrm{M} \mathrm{HCl}$ were added to $50 \mathrm{~mL}$ of sample and digestedevaporated at boiling temperature until $20 \mathrm{~mL}$ of sample were obtained. Afterward, samples were filtered and used for mineral analysis. Potassium and sodium were detected by emission at wavelengths of $589.6 \mathrm{~nm}$ and $769.9 \mathrm{~nm}$, respectively, while calcium, magnesium, iron, zinc, copper and manganese were determined by absorption at wavelengths of $422.7 \mathrm{~nm}, 285.2 \mathrm{~nm}$, $248.3 \mathrm{~nm}, 213.9 \mathrm{~nm}, 324.7 \mathrm{~nm}$ and $279.5 \mathrm{~nm}$, respectively. Results were expressed as milligrams per litre of sample $(\mathrm{mg} / \mathrm{L})$ based on calibration curves prepared with $0 \mathrm{mg} / \mathrm{L}$ to $100 \mathrm{mg} / \mathrm{L}$ for sodium and potassium; $0 \mathrm{mg} / \mathrm{L}$ to $10 \mathrm{mg} / \mathrm{L}$ for calcium, iron, magnesium and manganese; $0 \mathrm{mg} / \mathrm{L}$ to $5 \mathrm{mg} / \mathrm{L}$ for zinc and copper, standards of each mineral.

Nutraceutical properties

Phenolics evaluations were performed according to Niño-Medina et al [15]. Total phenols were carried out based in the Folin-Ciocalteu reaction, gallic acid was used as the standard ( $0 \mathrm{mg} / \mathrm{L}$ to $200 \mathrm{mg} / \mathrm{L}$ ) and results were expressed as milligrams of gallic acid equivalents per litre of sample (mg GAE/L). Total flavonoids were evaluated based on the aluminium chloride $\left(\mathrm{AlCl}_{3}\right)$ reaction, catechin was used as the standard $(0 \mathrm{mg} / \mathrm{L}$ to $200 \mathrm{mg} / \mathrm{L})$ and results were expressed as milligrams of catechin equivalents per litre of sample (mg CatE/L). Total non-flavonoids were obtained by subtraction between total phenols and total flavonoids.

Antioxidant capacity by DPPH (2,2-diphenyl-1-picrylhydrazyl) and ABTS (2,2'-azino-bis(3-ethylbenzothiazoline-6-sulfonic acid) diammonium salt) radicals were measured based on the reduction of the absorbance in the presence of sample according to Niño-Medina et al [15]. FRAP antioxidant capacity was measured based on the reaction of ferrous tripyridyltriazine complex in the presence of sample according to López-Conteras et al [12] and ORAC antioxidant capacity was measured based on the scavenging of peroxyl radicals generated by AAPH (2,2-azo-bis-2-methylpropionamide dihydrochloride) by sample, preventing degradation of fluorescein according to Urías-Orona et al [26]. Trolox was used as the standard for the four antioxidant capacity assays $(0 \mu \mathrm{mol} / \mathrm{L}$ to $200 \mu \mathrm{mol} / \mathrm{L})$ and results were expressed as micromoles of Trolox equivalents per litre of sample ( $\mu \mathrm{mol}$ TE/L). All phenolic and antioxidant evaluations were performed using Jenway 6705 UV/Vis spectrophotometer (Stone, Staffordshire, United Kingdom).

Statistical analysis

All the results were expressed as mean values of three samples \pm standard deviation. Statistical differences among samples were evaluated by analysis of variance (ANOVA) followed by Tukey's test using Minitab 14.0. A level of probability of $p<0.05$ was set as statistical significance.

\section{Results and Discussion}

\section{Physicochemical parameters}

The $\mathrm{pH}$ and titratable acidity are important quality attributes in alcoholic beverages. They are responsible for the taste, colour and also serve as preservative to extend the shelf life affecting the redox potential and microbial growth [25]. For most of the commercial beers $\mathrm{pH}$ values are from 4 to 5. Organic and carbonic acids are responsible for this acidity and they come from metabolic by-products of yeast cells or from malt and hop [4]. Also, the colour is a critical parameter 
FARMACIA, 2018, Vol. 66, 4

of beer quality and the main contributors to the beer colour are melanoidins and oxidized polyphenols. They came from raw materials and their chemical reactions are mainly produced during malting and wort production [9].

Table I

Physicochemical parameters of regular, light and zero beers

\begin{tabular}{|c|c|c|c|c|c|c|}
\hline \multirow{2}{*}{ Beer } & \multicolumn{6}{|c|}{ Physicochemical Parameters } \\
\hline & Alcohol $(\%)^{*}$ & $\mathrm{pH}$ & Total Acidity (\%) & Colour (EBC units) & Colour (ASBC units) & Colour View \\
\hline Regular & 4.50 & $4.05 \pm 0.009^{\mathrm{c}}$ & $0.177 \pm 0.002^{\mathrm{a}}$ & $6.29 \pm 0.053^{\mathrm{b}}$ & $3.19 \pm 0.027^{\mathrm{b}}$ & \\
\hline Light & 3.90 & $4.17 \pm 0.004^{b}$ & $0.140 \pm 0.001^{\mathrm{c}}$ & $5.78 \pm 0.035^{\mathrm{c}}$ & $2.93 \pm 0.018^{\mathrm{c}}$ & \\
\hline Zero & 0.00 & $4.25 \pm 0.001^{\mathrm{a}}$ & $0.153 \pm 0.003^{b}$ & $7.20 \pm 0.071^{\mathrm{a}}$ & $3.66 \pm 0.036^{\mathrm{a}}$ & \\
\hline
\end{tabular}

Regarding to the $\mathrm{pH}$ and titratable acidity, there were significant difference between the three types of beer. The values of $\mathrm{pH}$ were from 4.05 (regular beer) to 4.25 (zero beer), while the titratable acidity ranged from $0.140 \%$ (light beer) to $0.177 \%$ (regular beer). In addition, the colour values ranged from 5.78 to 7.20 and from 2.93 to 3.66 in EBC and ASBC units, respectively, being light and zero beers the lowest and highest, respectively (Table I).

Our data are in the range of those reported by Pai et al [16] who found values from 3.83 to 4.49 in $\mathrm{pH}$ and from $0.0957 \%$ to $0.2252 \%$ in titratable acidity of 15 pale lager beers commercialized in India with an alcohol content from $4.45 \%$ to $8.91 \%$. Popescu et al [19], produced a light lager beer at laboratory scale and obtained a product with $3.69 \%$ of alcohol, a $\mathrm{pH}$ of 4.23 , a titratable acidity of $0.295 \%$ and colour in EBC units of 13.2 (6.7 ASBC units). The physicochemical parameters obtained by these authors are different from our results since their $\mathrm{pH}$, titratable acidity and colour values were higher than the three types analysed in the present study.

On the other hand, Liguori et al [11] obtained an alcohol free beer $(<0.5 \%$ alcohol $)$ from a regular lager beer $(4.95 \%$ alcohol) by osmotic distillation and evaluated some physicochemical parameters in both products. The $\mathrm{pH}$ of the original lager beer was 4.13 and the colour in EBC units was 7.6 (3.9 ASBC units) but these values changed to 4.18 in $\mathrm{pH}$ and 8.4 in EBC colour units (4.3 ASBC units) after production of alcohol free beer. The $\mathrm{pH}$ of the original and alcohol free beers reported by these authors are similar to the data found in our study, but the colour obtained by them is different compared to our results.

\section{Mineral composition}

The natural components used for brewing (water, malt, hop and yeast) are the main sources of minerals in beer. According to relatively high contents of some minerals in beer, its moderate consumption can be considered a valuable source of their recommended daily dietary intakes [18].

Regarding to the mineral elements, there were significant differences $(p<0.05)$ in the content of all the minerals quantified in beer samples. Zero beer showed the highest content of calcium $(105.47 \mathrm{mg} / \mathrm{L})$, magnesium (93.16 mg/L), potassium (488.16 mg/L), sodium $(137.62 \mathrm{mg} / \mathrm{L})$, while light beer contained the highest amount of copper $(0.065 \mathrm{mg} / \mathrm{L})$, zinc $(0.038 \mathrm{mg} / \mathrm{L})$ and iron $(0.065 \mathrm{mg} / \mathrm{L})$. On the other hand, manganese was found only in the regular beer sample $(0.048 \mathrm{mg} / \mathrm{L})$ (Table II).

Table II

Mineral content of regular, light and zero beers

\begin{tabular}{|c|c|c|c|c|c|c|c|c|}
\hline \multirow{2}{*}{ Beer } & \multicolumn{4}{|c|}{ Minor Elements (mg/L) } & \multicolumn{4}{|c|}{ Major Elements (mg/L) } \\
\hline & $\mathrm{Cu}$ & $\mathrm{Mn}$ & $\mathrm{Zn}$ & $\mathrm{Fe}$ & $\mathrm{Ca}$ & $\mathrm{Mg}$ & $\mathrm{K}$ & $\mathrm{Na}$ \\
\hline Regular & $0.044 \pm 0.003^{b}$ & $0.048 \pm 0.008^{\mathrm{a}}$ & $0.035 \pm 0.005^{\mathrm{a}}$ & $0.076 \pm 0.003^{\mathrm{c}}$ & $99.49 \pm 0.13^{b}$ & $68.38 \pm 0.04^{b}$ & $252.09 \pm 3.13^{b}$ & $94.09 \pm 0.34^{\mathrm{b}}$ \\
\hline Light & $0.065 \pm 0.002^{\mathrm{a}}$ & ND & $0.038 \pm 0.002^{\mathrm{a}}$ & $0.112 \pm 0.002^{\mathrm{a}}$ & $70.66 \pm 0.29^{c}$ & $48.35 \pm 0.11^{\mathrm{c}}$ & $187.76 \pm 0.74^{\mathrm{c}}$ & $104.79 \pm 4.88^{b}$ \\
\hline Zero & $0.041 \pm 0.003^{b}$ & ND & $0.038 \pm 0.010^{\mathrm{a}}$ & $0.093 \pm 0.004^{\mathrm{b}}$ & $105.47 \pm 0.15^{\mathrm{a}}$ & $93.16 \pm 0.48^{\mathrm{a}}$ & $488.16 \pm 9.85^{\mathrm{a}}$ & $137.62 \pm 0.44^{\mathrm{a}}$ \\
\hline
\end{tabular}

Values with different letters within same column are significantly different $(\mathrm{p}<0.05, \mathrm{n}=3)$. ND $=$ Not detected.

Rodrigo et al [20], analysed seven Mexican commercial lager beers finding average levels of calcium $(50.4$ $\mathrm{mg} / \mathrm{L})$ and sodium $(53.1 \mathrm{mg} / \mathrm{L})$ lower than our results. On the contrary, copper $(0.677 \mathrm{mg} / \mathrm{L})$, manganese $(0.10 \mathrm{mg} / \mathrm{L})$, iron $(0.332 \mathrm{mg} / \mathrm{L})$ and zinc $(0.189 \mathrm{mg} / \mathrm{L})$ were higher than found in our samples. In addition, the content of potassium $(239 \mathrm{mg} / \mathrm{L})$ and magnesium $(57.3 \mathrm{mg} / \mathrm{L})$ was similar to our regular and light beers, respectively.

Alcázar et al [1], analysed the content of minerals in commercial lager (10 brands) and low alcohol (18 brands) beers. They observed that the average content of calcium, magnesium and potassium were $13.63 \%$, $33.80 \%$ and $21.69 \%$ higher in lager beers than in low alcohol beers, respectively. In the present study it was observed the same behaviour in the same elements between regular and light beers being the first one $28.98 \%, 29.30 \%$ and $25.52 \%$ higher than the latter one in calcium, magnesium and potassium, respectively. On the contrary to their results, we found that light beer obtained higher values than regular beer in copper, iron and sodium. 
FARMACIA, 2018, Vol. 66, 4

Nutraceutical properties

Phenolic compounds are interesting metabolites due to their abundance in the human diet, their antioxidant properties and their potential role in the prevention of several diseases associated with oxidative stress [13]. Several thousands of phenolic compounds have been identified in plants and processed foods. Although is almost impossible to know the nature of all the phenolics present in a single sample, it is desirable to know the main classes of phenolic compounds present in it [21].

In relation to the phenolics quantified in beer samples, there were significant differences $(p<0.05)$ in the content of total phenolics, total flavonoids and total

nonflavonoids between the three types of beer. In total phenols, regular beer obtained the highest content with $140.70 \mathrm{mg}$ GAE/L, followed by zero beer with $125.30 \mathrm{mg} \mathrm{GAE} / \mathrm{L}$ and light beer obtained the lowest concentration with $72.32 \mathrm{mg} \mathrm{GAE} / \mathrm{L}$. The same behaviour was observed in total non-flavonoids in which regular beer, zero beer and light beer obtained $101.70 \mathrm{mg} \mathrm{GAE} / \mathrm{L}, 65.80 \mathrm{mg}$ GAE/L and $46.82 \mathrm{mg} \mathrm{GAE} / \mathrm{L}$, respectively. In total non-flavonoids, zero beer obtained the highest content registering $59.50 \mathrm{mg} \mathrm{GAE} / \mathrm{L}$, followed by regular beer with $39.00 \mathrm{mg} \mathrm{GAE} / \mathrm{L}$ and the lowest content was found in light beer with $25.50 \mathrm{mg}$ GAE/L (Table III).

Table III

Nutraceutical evaluation of regular, light and zero beers

\begin{tabular}{|c|c|c|c|c|c|c|c|}
\hline \multirow{2}{*}{ Beer } & \multicolumn{3}{|c|}{ Phenolics (mg/L) } & \multicolumn{4}{|c|}{ Antioxidant Capacity $(\mu \mathrm{mol} \mathrm{TE} / \mathrm{L})$} \\
\hline & Total phenols & Total flavonoids & Total non-flavonoids & ABTS & DPPH & FRAP & ORAC \\
\hline Regular & $140.70 \pm 1.91^{\mathrm{a}}$ & $39.00 \pm 2.83^{b}$ & $101.70 \pm 0.92^{\mathrm{a}}$ & $643.57 \pm 19.19^{\mathrm{a}}$ & $684.00 \pm 4.71^{\mathrm{a}}$ & $622.28 \pm 7.86^{\mathrm{a}}$ & $1252.16 \pm 3.14^{\mathrm{a}}$ \\
\hline Zero & $125.30 \pm 1.53^{\mathrm{b}}$ & $59.50 \pm 2.12^{\mathrm{a}}$ & $65.80 \pm 3.65^{b}$ & $559.29 \pm 21.21^{\mathrm{b}}$ & $657.33 \pm 7.07^{\mathrm{b}}$ & $520.89 \pm 3.54^{\mathrm{b}}$ & $1216.36 \pm 3.37^{\mathrm{b}}$ \\
\hline
\end{tabular}

Values with different letters within same column are significantly different $(\mathrm{p}<0.05, \mathrm{n}=3)$

In terms of percentage, regular beer was $48.59 \%$ and $10.94 \%$ higher than light and zero beers in total phenols, and $53.96 \%$ and $35.29 \%$ higher than light beer in total non-flavonoids, respectively. Zero beer was $34.45 \%$ and $57.14 \%$ higher than regular and light beer in total flavonoids, respectively. The nonflavonoids compounds were the main phenolic group in all samples, accounting for $72.28 \%, 64.74 \%$ and $52.51 \%$ of the total phenolic, in regular, light and zero beers, respectively.

Several studies about phenolic compounds have been carried out in regular beers, but data of these evaluations in low and alcohol free beers are limited. Mitić et al [14], evaluated 15 regular lagers and 3 alcohol-free commercially beers and they reported that the mean value of regular beers was $19.01 \%$ and $10.72 \%$ higher than alcohol free beers in total phenolics and total flavonoids, respectively. Piazzon et al [17], showed a very similar finding in total phenolics reporting that regular beer had $19.02 \%$ more phenolics than dealcoholized beers analysing five different brands of each type. The results obtained by these authors are different to ours, since we found a small difference between regular and zero beer in total phenols, but a large difference between these two beers in total flavonoids.

It is of great interest from different points of view (consumers, food science researchers, nutritional experts) to know the antioxidant capacity of the foods that we consume [8]. The objective to determine the efficacy of antioxidants in protection against oxidative damage is to avoid the loss of commercial and nutritional value and thus a rapid method for determining antioxidant capacity of foods is desirable [22].
In relation to the antioxidant capacity, there were significant differences $(p<0.05)$ in all assays between the three types of beer. The values of antioxidant capacity ranged from $286 \mu \mathrm{mol} \mathrm{TE} / \mathrm{L}$ to $643 \mu \mathrm{mol}$ TE/L, $381 \mu \mathrm{mol} \mathrm{TE} / \mathrm{L}$ to $684 \mu \mathrm{mol} \mathrm{TE} / \mathrm{L}, 474 \mu \mathrm{mol}$ $\mathrm{TE} / \mathrm{L}$ to $622 \mu \mathrm{mol} \mathrm{TE} / \mathrm{L}$ and $1201 \mu \mathrm{mol} \mathrm{TE} / \mathrm{L}$ to $1252 \mu \mathrm{mol}$ TE/L in ABTS, DPPH, FRAP and ORAC respectively and the behaviour in all the antioxidant capacity assays was: regular beer $>$ zero beer $>$ light beer (Table III).

Regular beer was higher than zero beer by $13.10 \%$, $3.90 \%, 16.30 \%$ and $2.86 \%$ in ABTS, DPPH, FRAP and ORAC assays, respectively. On the other hand, regular beer had a better antioxidant capacity with $55.50 \%, 44.23 \%, 23.71 \%$ and $4.05 \%$ than light beer in the same analyses, respectively.

Tafulo et al [24], evaluated the antioxidant capacity using the same assays as in our work, using 10 regular ( $5 \%$ alcohol), 3 light ( $4 \%$ alcohol) and 4 zero $(0 \%$ alcohol) commercial beers. These authors had the same observations in the FRAP assay in which the average values of regular beers were $5.6 \%$ and $14.1 \%$ than light and zero beers, respectively. A different behaviour was observed by them in ABTS and ORAC assays in which, zero beers showed the highest antioxidant capacity followed by regular and light beers. According to these authors, zero beer was $1.9 \%$ and $2.8 \%$ higher than light and zero beers in ABTS assay and $4.3 \%$ and $15.2 \%$ higher than light and zero beers in ORAC. Finally they observed that light beers had the highest antioxidant capacity in DPPH assay being $14.8 \%$ and $30.2 \%$ higher than zero and regular beers, respectively. 


\section{Conclusions}

Due to the diverse options of different alcohol content beers on the market for consumers, it is necessary to evaluate the differences in quality, nutritional and nutraceutical aspects. Although all samples were in the range of the quality criteria in the physicochemical parameters there were statistical differences between them. On the other hand, zero beer showed higher contents of some important nutritional mineral elements (Ca, $\mathrm{Mg}, \mathrm{K}, \mathrm{Na}$ ) than regular and light beers. In addition, regular beer presented the highest levels in nutraceutical properties (phenolics and antioxidant capacity). The results obtained in the present work give information to consumers for choosing a beer based on the physicochemical, nutritional and nutraceutical properties.

\section{References}

1. Alcázar A, Pablos F, Martín MJ, González AG, Multivariate characterisation of beers according to their mineral content. Talanta, 2002; 57: 45-52.

2. Association of Official Analytical Chemist (AOAC). Official Methods of Analysis of AOAC International, $16^{\text {th }}$ ed. Maryland, USA, 1998.

3. Astrup A, Estruch R, Hendriks H, Kok F, Marcos A, Solfrizzi V, Zugravu CA, Beer and health - Moderate consumption as part of a healthy lifestyle. Beer and Health, 2016; 1-127.

4. Buiatti S, Chapter 20 Beer Composition: An overview. In: Beer in Health and Disease Prevention. Preedy VR, ed. Academic Press, London, UK, 2009; 213-225.

5. Collin S, Jerkovic V, Bröhan M, Callemien D, Phenolics: Biological activity and bioavailability. Chapter 75 Polyphenols and beer quality. In: Natural products: Phytochemistry, botany and metabolism of alkaloids, phenolics and terpenes. Part VIII. KG Ramawat JM, Mérillon, eds. Springer, Berlin, Germany, 2013; 2334-2359.

6. de Gaetano G, Costanzo S, Di Castelnuovo A, Badimon L, Bejko D, Alkerwi A, Chiva-Blanch G, Estruch R, La Vecchia C, Panico S, Pounis G, Sofi F, Effects of moderate beer consumption on health and disease: A consensus document. Nutr Metab Cardiovasc Dis., 2016; 26: 443-467.

7. Gerhäuser C, Beer constituents as potential cancer chemopreventive agents. Eur J Cancer, 2005; 41: 1941-1954.

8. Huang D, Ou B, Prior RL, The chemistry behind antioxidant capacity assays. J Agr Food Chem., 2005; 53: 1841-1856.

9. Hughes PS, Baxter ED, Chapter 2 Beer quality and the importance of visual cues. In: Beer: Quality, safety and nutritional aspects. Royal Society of Chemistry, Cambridge, 2001; 15-39.

10. Liu J, Zhu Y, Liu Yan, Liu J, Wu Y, Luo S, Zhou X, Hao Y, Correlation between alcohol consumption and myocardial infarction: dose-response meta-analysis of 18 cohort studies. Farmacia, 2017; 65(1): 5-13.
11. Liguori L, De Francesco G, Russo P, Perretti G, Albanese D, Di Matteo M, Production and characterization of alcohol-free beer by membrane process. Food Bioprod Process., 2015; 94: 158-168.

12. López-Contreras JJ, Zavala-García F, Urías-Orona V, Martínez-Ávila GCG, Rojas R, Niño-Medina G, Chromatic, phenolic and antioxidant properties of Sorghum bicolor genotypes. Not Bot Horti Agrobot., 2015; 43: 366-370.

13. Manach C, Scalbert A, Morand C, Rémésy C, Jiménez L, Polyphenols: Food sources and bioavailability. Am J Clin Nutr., 2004; 79: 727-747.

14. Mitić SS, Paunović DĐ, Pavlović AN, Tošić SB, Stojković MB, Mitić MN, Phenolic profiles and total antioxidant capacity of marketed beers in Serbia. Int J Food Prop., 2014; 17: 908-922.

15. Niño-Medina G, Romo-Longoria JD, Ramírez-González IV, Martínez-Reyna OO, Urías-Orona V, Phenolic content and antioxidant capacity level in commercial Mexican lager beers. J Am Soc Brew Chem., 2017; 75: 156-158.

16. Pai TV, Sawant SY, Ghatak AA, Chaturvedi PA, Gupte AM, Desai NS, Characterization of Indian beers: chemical composition and antioxidant potential. J Food Sci Technol., 2015; 52: 1414-1423.

17. Piazzon A, Forte M, Nardini M, Characterization of phenolics content and antioxidant activity of different beer types. J Agr Food Chem., 2010; 58: 10677-10683.

18. Pohl P, Chapter 33 Metals in beer. In: Beer in health and disease prevention. Preedy VR, ed. Academic Press, London, UK, 2009; 349-358.

19. Popescu V, Soceanu A, Dobrinas S, Stanciu G, A study of beer bitterness loss during the various stages of the Romanian beer production process. J Ins. Brew., 2013; 119: 111-115.

20. Rodrigo S, Young SD, Talaverano MI, Broadley MR, The influence of style and origin on mineral composition of beers retailing in the UK. Eur Food Res Technol., 2017; 243: 931-939.

21. Scalbert A, Williamson G, Dietary intake and bioavailability of polyphenols. $J$ Nutr., 2000; 130: 2073S-2085S

22. Singh S, Singh RP, In vitro methods of assay of antioxidants: An overview. Food Rev Int., 2008; 24: 392-415.

23. Sohrabvandi S, Mousavi SM, Razavi SH, Mortazavian AM, Rezaeil K, Alcohol-free beer: methods of production, sensorial defects, and healthful effects. Food Rev Int., 2010; 26: 335-352.

24. Tafulo PAR, Queirós RB, Delerue-Matos CM, Sales MGF, Control and comparison of the antioxidant capacity of beers. Food Res Int., 2010; 43: 1702-1709.

25. Tüsekwa AB, Mosh TCE, Laswai HS, Towo EE, Traditional alcoholic beverages of Tanzania: Production, quality and changes in quality attributes during storage. Int J Food Sci Nutr., 2000; 51: 135-143.

26. Urías-Orona V, Heredia JB, Muy-Rangel D, NiñoMedina G, Phenolic acids with antioxidant activity in maize bran and wheat bran. Ecosistemas $y$ Recursos Agropecuarios, 2016; 3: 43-50. 